\title{
REGULATIONS OF PETER THE GREAT IN THE ASPECT OF IMPERATIVENESS ${ }^{1}$
}

\author{
Dmitriy V. Rudnev \\ Herzen State Pedagogical University of Russia, Saint Petersburg, Russia \\ Natalia V. Pushkareva \\ St. Petersburg State University, Saint Petersburg, Russia
}

\begin{abstract}
In the era of Peter the Great, a new genre of regulations appeared in the Russian official language, with the help of which the authorities tried to introduce new, European principles of governing the country in Russia. The authors of the regulations were faced with the difficult task of finding speech means adequate to the new genre, corresponding both to the communicative tasks and to the addressee of the regulations. The performed analysis demonstrates a significant update of the means of the official language used in the Peter's regulations. In particular, the ways of expressing imperative have undergone a significant transformation. Along with the independent infinitive, which was inherited from pre-Petrine official speech, imperativeness begins to be expressed by various lexical means - both Russian and borrowed in origin (Polonisms, Germanisms, Latinisms): modifiers dolzhen 'must', imet' 'have to', nadlezhit 'should', prinuzhden 'be forced', etc. in combination with the infinitive, a particle $d a$ 'let' in combination with a verb in the present or future tense, etc. The models differed not only in origin and stylistic coloring, but also in their compatibility. Changes in the system of imperative means were due to various reasons - semantic (the need to more accurately express the imperative meaning), stylistic (the desire to make a business text more bookish, to tear it away from the colloquial basis), socio-cultural (the influence of European text patterns and socio-cultural models).

Key words: business language, history of business Russian, $18^{\text {th }}$ century, Petrine epoch, regulations, imperativeness, modal modifier, intensifier.

Citation. Rudnev D.V., Pushkareva N.V. Regulations of Peter the Great in the Aspect of Imperativeness. Vestnik Volgogradskogo gosudarstvennogo universiteta. Seriya 2. Yazykoznanie [Science Journal of Volgograd State University. Linguistics], 2021, vol. 20, no. 4, pp. 36-49. (in Russian). DOI: https://doi.org/10.15688/ jvolsu2.2021.4.3
\end{abstract}

УДК $811.161 .1 ’ 38$

ББК 81.411.2-55

Дата поступления статьи: 11.02.2021

Дата принятия статьи: 11.05.2021

\section{РЕГЛАМЕНТЫ ПЕТРОВСКОГО ВРЕМЕНИ В АСПЕКТЕ ИМПЕРАТИВНОСТИ ${ }^{1}$}

\section{Дмитрий Владимирович Руднев}

Российский государственный педагогический университет им. А.И. Герцена, г. Санкт-Петербург, Россия

Наталия Викторовна Пушкарева

Санкт-Петербургский государственный университет, г. Санкт-Петербург, Россия

Аннотация. В период правления Петра I в русском деловом языке возникает жанр регламента, при помощи которого в России внедрялись новые, европейские принципы управления страной. Это обусловило поиск адекватных новому жанру речевых средств, соответствовавших его коммуникативным задачам и ориентированных на определенного адресата документа. Материалом для анализа послужили Артикул воинский, Генеральный регламент и Регламент о управлении Адмиралтейства и верфи. Результаты проведенного исследования демонстрируют существенное обновление средств делового языка, использованных в петров- 
ских регламентах. Показано, что значительной трансформации подверглись способы выражения императивности. Установлено, что наряду с независимым инфинитивом, унаследованным из допетровской деловой речи, императивность начинает выражаться разнообразными конструкциями, содержащими русские и заимствованные лексические единицы (полонизмы, германизмы, латинизмы): модальными модификаторами должен, иметь, надлежит, принужден и др. в сочетании с инфинитивом, частицей да в сочетании с глаголом в настоящем или будущем времени и проч. Выявлены сочетаемостные различия средств выражения императивности в регламентах. Аргументировано, что изменения в системе императивных средств были обусловлены различными причинами: семантическими (необходимость точнее выразить императивное значение), стилистическими (стремление «окнижить» деловой текст), социокультурными (ориентация на европейские текстовые образцы и социокультурные модели).

Ключевые слова: деловая речь, история русского делового языка, XVIII век, Петровская эпоха, регламент, императивность, модальный модификатор, интенсификатор.

Цитирование. Руднев Д. В., Пушкарева Н. В. Регламенты петровского времени в аспекте императивности // Вестник Волгоградского государственного университета. Серия 2, Языкознание. - 2021. - Т. 20, № 4. C. 36-49. -DOI: https://doi.org/10.15688/jvolsu2.2021.4.3

\section{Введение}

Современную административную культуру невозможно представить без регламентирующих документов, в которых «в целях упорядочения определенного участка деятельности зафиксированы те или иные часто повторяющиеся операции участников процесca, а также сроки исполнения тех или иных технологических операций» [Шарипова, 2014, c. 83]. Регламенты определяют функции и задачи, полномочия и ответственность, связи, средства поощрения и принуждения участников процесса.

Регламентирующие тексты современного типа появляются в России на рубеже XVIIXVIII вв. под влиянием европейских образцов, что было обусловлено стремлением Петра I создать регулярное государство европейского типа, воплотившимся прежде всего в изменении принципов управления страной под влиянием европейской политической теории, представлявшей государство в виде механизма. Построение государства на основе принципов механики побуждало власть к регламентации действий жителей страны при выполнении должностных обязанностей.

В допетровский период деловым жанром, имеющим некоторые признаки регламентов, была наказная память. Этот жанр известен с середины XVI в. и был одной из разновидностей памяти, по определению А.Н. Качалкина, документа, представляющего собой распоряжение, предписание старшего по положению лица или учреждения на конкретные действия своим подчиненным [Качалкин, 1989, с. 26]. Например:
Лета 7107 Генваря в 15 день, по Государеву Цареву и Великого Князя Бориса Федоровича всеа Русии указу, память Григорью Чернышову. Ехати ему по Переславской дороге до села до Тонинскаго и где встретит, с Сибирскими царевичи и с царицами, Савина Воейкова с товарыщи; а где встретит, и Григорью говорить Савину Воейкову с товарыщи, чтоб оне ехали с Сибирскими царевичи и с царицами в Троецкое село въ Ростокино, а в Ростокине б с царевичи ночевали и были б наготове... (Память Григорию Чернышову о удержании Кучюмова семейства в селе Ростокине до государева указа, 15 января 1599 г.) (АИ, с. 16).

Наказные памяти составлялись в приказе или местном учреждении и, наделяя лицо полномочиями для выполнения какого-либо конкретного поручения, содержали инструкцию по его выполнению. Имея некоторые признаки инструкции, наказная память была лишена важных признаков регламентирующих документов - повторяемости регламентируемых действий и, как следствие, деперсонифицированности.

В петровское время появляется ряд регламентов, определивших жизнь страны на много десятилетий вперед: «Артикул воинский» (1715), «Устав воинский сухопутный» (1716), «Морской устав» (1720), «Генеральный регламент» (1720), «Духовный регламент» (1721), «Регламент Главному магистрату» (1721), «Регламент о управлении Адмиралтейства и верфи» (1722).

Регламенты не подменяли волю государя, а были особой текстовой формой ее постоянной трансляции. Так, в предисловии к Артикулу воинскому говорилось: «Повелева- 
ем всем обще нашим генералам, штаб-, обери унтер-офицерам и солдатам, как подданным, так и чужестранным в службе нашей пребывающим, послушным и покорным быть по своей должности и все пункты сего Артикула право исполнять...» (AB, с. 1$)$; аналогичное этому указание видим в Генеральном регламенте: «Того ради его императорское величество за потребно рассудить изволил всем в вышеписанных государственных коллегиях обретающимся вышним и нижним служителям обще и каждому особо сим генеральным регламентом во известие и вместо генеральной инструкции (наказу) всемилостивейшее свое повеление в нижеписанных главах объявить» (ГР, с. 2). В присутствии императора его воля оказывалась выше предписаний регламента: «...где его царское величество своею высокою особою присудствен, то всех начальников власть и сила отнята есть, кроме тех, которым от его величества нарочно что управлять повелено будет» (AВ, с. 18).

Регламенты были ориентированы на коллективного адресата, в том числе и на тех, кто не был обучен грамоте: так, военные регламенты регулярно читались перед строем или во время приема пищи (в последнем случае можно усмотреть приспособление монастырской традиции чтения жития святых во время общей трапезы). Возможность чтения регламентов перед строем следует принимать во внимание при анализе используемых в них речевых средств.

Петровские регламенты характеризуются значительной новизной используемых языковых ресурсов, в том числе средств выражения императивности (побуждения, волеизъявления). Этому можно дать два объяснения: с одной стороны, регламентирующие тексты как новый жанр требовали новых речевых средств, с другой стороны, установка на новизну имела во многом осознанный характер: новые речевые средства должны были подчеркнуть противопоставление нового регулярного государства, новой управленческой культуры предшествующей традиции. Кроме того, были и иные причины - семантического и стилистического порядка, - о которых будет сказано ниже.

Цель статьи - описать средства выражения императивности в регламентах петров- ского времени. Актуальность такого исследования обусловлена тем, что петровские регламенты явились первыми по времени русскими регламентами и отразили изменения как в административной культуре страны, так и в языке управления. Изучение истории формирования средств выражения императивности помогает глубже понять современную систему этих средств в деловых текстах, в частности в регламентах.

\section{Материал и методы}

Материалом для наших наблюдений послужили три регламента - Артикул воинский, Генеральный регламент и Регламент о управлении Адмиралтейства и верфи. Выбранные для лингвистического анализа регламенты регулировали разные стороны жизни страны (военную и гражданскую) и связаны с разными периодами законотворческой деятельности Петра I. Это позволило корректно описать репертуар средств выражения императивности в текстах регламентов петровского времени, проследив возможную зависимость использования этих средств от тематики и адресата регламента, а также от времени его создания.

В работе использованы описательный, сравнительно-исторический методы, контекстуальный, валентностный анализ, прием количественных подсчетов.

Остановимся на понятии императивности, используемом в статье. Деловое общение (а следовательно, и тексты, при помощи которых оно осуществляется) «характеризуется ярко выраженной стратегией воздействия адресанта на адресата с целью побуждения второго к совершению определенного (чаще всего посткоммуникативного) действия» [Комлева, 2003, с. 4-5], цель делового общения - «предписать типовому адресату нормы поведения и установить порядок осуществления деятельности в конкретной деловой сфере» [Ширинкина, 2018, с. 120].

В стилистике эту черту деловой речи описывают как стилевую окраску долженствования, побудительность, директивность, предписывающий характер (прескриптивность), императивность и т. д. В правоведении основными способами правового воздействия при- 
знаются запрет, дозволение и позитивное обязывание, в качестве дополнительных - утверждение, рекомендация, поощрение и др. [Бошно, 2014, с. 55-60].

Обязывание выражается широким набором средств: лексемами с семой волеизъявления (обязанность, полномочия), глагольной формой настоящего предписания, модальноинфинитивными конструкциями (с модальными операторами должен, обязан, следует), речевыми клише (в установленном порядке и др.) и проч. Семантика дозволения (необязательного следования) выражается лексемами вправе, допускается, разрешается в сочетании с инфинитивом или отглагольным существительным; семантика запрета - сочетаниями отрицательной частицы не и лексем вправе, мочь, допускаться, разрешаться.

«В документе может происходить как усиление категоричности предписания, так и ее уменьшение» [Ширинкина, 2018, с. 125]. Интенсивность реализуется как мера волеизъявления различными средствами, в частности прилагательными, наречиями, усиливающими или смягчающими степень категоричности (только, обязательный, обязательно, исключительныц̆, исключительно, всегда, не позже), при помощи возможного выбора синонима (должен и обязан), предпочтения при выборе вида глагола (подробно о средствах реализации интенсивности см.: [Ширинкина, 2018; Орлова, 2014]).

Эмоциональность документного текста зависит от способов реализации волеизъявления, соотношения семантики обязывания, дозволения и запрета, от наличия в тексте интенсификаторов волеизъявления. Так, имплицитный способ выражения обязывания (настоящее долженствования) формирует эмоционально нейтральный тон, тогда как «высказывания с эксплицитным императивом, акцентирующие волеизъявление, в эмоциональном плане дальше от нулевой точки шкалы» [Opлова, 2014, с. 193].

Наряду с пониманием императивности как стилистической окраски делового текста существует ее семантическое толкование, представленное, например, в работах А.В. Бондарко, описывающего ее через понятие императивной ситуации - «типовой содержательной структуры, основными элементами которой являются: 1) субъект волеизъявления $\left(\mathrm{C}_{1}\right)$, 2) субъект-исполнитель $\left.\left(\mathrm{C}_{2}\right), 3\right)$ предикат, раскрывающий содержание волеизъявления, исходящего от $\mathrm{C}_{1}$ и обращенного к $\mathrm{C}_{2}$ : каузируется действие (в широком смысле), направленное на преобразование пока (в момент волеизъявления $\mathrm{t}_{1}$ ) ирреальной ситуации в ситуацию, которая по замыслу говорящего должна стать в результате каузируемого действия (в момент или период $\mathrm{t}_{2}$ ) реальной» [Бондарко, 1990, с. 80]. В дальнейшем в статье используются понятия субъекта волеизъявления и субъекта-исполнителя, предложенные А.В. Бондарко.

\section{Результаты и обсуждение}

\section{Средства выражения императивности в петровских регламентах}

В деловом языке XVI-XVII вв. основным средством выражения императивности был инфинитив, реже использовались формы сослагательного наклонения глагола. По словам М.А. Соколовой, в «Судебнике» 1550 г. «все статьи, излагающие то или иное установление, пользуются исключительно формой инфинитива» [Соколова, 1952, с. 58]. Схожую ситуацию можно наблюдать в тексте «Соборного уложения» 1649 г., а также и в иных документах светской власти (см. также: [Колобкова, 1995, с. 15-16]). В регламентах петровского времени набор средств выражения императивности существенно расширяется.

\section{Выражение обязывания}

Обратимся к количественному распределению разных средств выражения обязывания. В Артикуле воинском встретились такие способы, как: «иметь + инфинитив» (155 случаев), «надлежст + инфинитив» (68), формы будущего времени со значением предписания (58), независимый инфинитив (33) ${ }^{2}$, формы настоящего долженствования (24), «должен + инфинитив» (23), «долженству$e m+$ инфинитив» (12), «надобно + инфинитив» (9), «бывать + страдательное причастие» (9), «да + будущее время глагола» (7), «принуж$\partial е н+$ инфинитив» (7) и некоторые другие (должно (3), потребно (3), обязан (1) и проч.). 
Как можно видеть из приведенных данных, главным способом выражения были модальные операторы иметь, надлежит в сочетании с инфинитивом и формы будущего времени со значением долженствования. Инфинитив оказывается далеко не самой частотной формой в Артикуле.

Средства выражения обязывания в Генеральном регламенте в целом те же, но их количественное распределение оказывается иным: «надлежит + инфинитив» (77 случаев), независимый инфинитив (49), «иметь + инфинитив» (47), формы настоящего долженствования (41), «должен + инфинитив» (21), формы будущего времени со значением долженствования (12), «повинен + инфинитив» (7), «долженствовать + инфинитив» (5), «должность есть + инфинитив» (5) и некоторые другие.

В Адмиралтейском регламенте средства выражения обязывания распределяются следующим образом: независимый инфинитив (729 случаев), «должен + инфинитив» (318), «надлежит + инфинитив» (253), формы будущего времени со значением долженствования (69), «чтоб + л-форма глагола» (55), «иметь + инфинитив» (37), «повинен + инфинитив» (33), «должно + инфинитив» (16). Единичными случаями представлены такие средства выражения обязывания, как формы настоящего долженствования (6), «надобно + инфинитив» (5), «повинно + инфинитив» (2), «долженству$e m+$ инфинитив» (2) и др. При сопоставлении с данными Артикула воинского обнаружено, что конструкция «иметь + инфинитив» реализуется редко, а в Адмиралтейском регламенте фиксируется увеличение доли независимого инфинитива. Можно предположить, что малая представленность конструкции «иметь + инфинитив» обусловлена нечеткостью выражения ею предписывающей модальности регламента.

В некоторых случаях средства выражения обязывания употреблены как синонимичные:

(1) Ежели кто комуприкажет кого смертно убить, оный тако ж, яко убийца, сам имеет казнен быть смертью, а имянно голову ему отсечь (АВ, с. 122);

(2) ...оный [утаивший государственные деньги] живота лишится и имеет быть повешен. Тую же казнь чинить и тем, кои ведая про то, а не известят (AB, с. 142).

Однако замена была возможна не всегда, что обусловлено различиями в семантике этих средств, особенностями их левосторонней (субъектной) и правосторонней сочетаемости, выбором между личной и безличной моделью выражения обязывания, а также стилистическими причинами. Кроме того, немаловажными оказываются прагматические факторы - особенности адресата, способ донесения содержания регламента до адресата, способ обязывания и др.

Охарактеризуем средства эксплицитного выражения обязывания.

Ярким средством выражения обязывания является речевая формула его императорское величество повелевает:

(3) Его императорское величество повелевает, чтоб никто не дерзал, какого б чина и достоинства он ни был, в камеру судейского правления входить... (ГР, с. 18).

Основным средством выражения обязывания в допетровской деловой письменности было инфинитивное предложение. Оно продолжает употребляться и в регламентах. Доля таких предложений в исследуемых документах неодинакова: так, в Адмиралтейском регламенте они составляют большинство случаев выражения обязывания. Независимый инфинитив предпочтителен в заголовках к статьям регламентов:

(4) Леса на боты и шлюпки подряжать возить сухие в крытых судах (АР, с. 8),

а в статьях регламентов - при описании последовательности выполнения каких-либо действий:

(5) Ежели кто отца своего, мать, дитя во младенчестве, офицера наглым образом умертвит, онаго колесовать, а тело его на колесо положить, а за прочих мечем наказать (AB, с. 123).

Кроме инфинитивного предложения, использовались другие односоставныепредложения для выражения обязывания, содержащие конструкции «надлежит + инфинитив», «должно + инфинитив», «надобно + инфинитив», 
«нужно + инфинитив» и проч. Предложения с глаголом надлежит 'должно, нужно, следует' (СлРЯ XVIII, вып. 13, с. 174) получают широкое распространение в петровское время, хотя практически неизвестны в предшествующую эпоху (не исключено, что модель является результатом польского влияния [Besters-Dilger, 1997, p. 21]). В регламентах конструкция «надлежит + инфинитив»- одна из самых частотных для выражения обязывания:

(6) Прежде надлежит в верьху листа год и число написать, потом присудствующие члены записать и потом протокол держать (ГР, с. 23).

На первый взгляд, безличная конструкция «надлежит + инфинитив» дублирует инфинитивную. Однако это справедливо лишь отчасти. Во-первых, введение в инфинитивное предложение модального оператора надлежит меняет стилистическую окраску конструкции: инфинитивное предложение связано с разговорной речью, из которой проникло в деловые документы; введение надлежит придает выражению обязывания книжную окраску. Окнижение, олитературивание деловой речи - одна из тенденций Петровской эпохи. Во-вторых, модальность инфинитивного предложения неоднозначна: инфинитивное предложение могло, помимо обязывания, выражать значение возможности. Введение модального оператора надлежит снимает неоднозначность. В-третьих, инфинитив обычно сопровождается дательным субъекта. Предложения с надлежсит также могут включать в свой состав дательный субъекта:

(7) А ежели в таких корреспонденциях какое непотребное замедление учинится, в том особливо президенту ответствовать надлежит... (ГР, с. 14).

Однако часто предложение не содержит указания на субъект, отчего предписание приобретает более обобщенный характер. Кроме того, модальный оператор надлежит изредка употребляется и в двусоставном предложении (хотя и с неактивным грамматическим субъектом):

(8) ...которые [указы] надлежат быть письменные и зарученые, а не словесные... (ГР, с. 6).

При реализации семантики обязывания в двусоставных предложениях субъект-испол- нитель предписываемого действия находится в позиции подлежащего (в инфинитивном предложении он выражен субъектным дополнением). Множество способов выражения обязывания в двусоставном предложении, встречающихся в текстах регламентов, по-видимому, следует рассматривать как поиск наиболее точной модели, которая еще не грамматикализировалась в русском языке. В современном деловом языке чаще всего используются краткие модальные прилагательные должен и обязан. В регламентах петровского времени европейская калька обязан еще не получила распространения и встречается лишь в единичных случаях:

(9) Ежели кто с девкою пребудет или очреватит ее под уговором, чтоб на ней жениться, то он сие содержать и на чреватой жениться весьма обязан (AB, с. 131-132).

В значении 'обязан' в регламентах изредка встречаются лексические единицы повинен или принужден:

(10) Такожде надлежит ему [переводчику] свой перевод во свидетельство подписывать: сие повинен он исполнять под такими ж штрафами и наказаниями, как в должности секретарской написано (ГР, с. 25);

(11) А офицер, ежели знатной причины в том не объявит, тогда за рядового несколько времяни служить принужден будет (AB, с. 59).

Полонизм повинен (powinien) в XV в. проник в украинский и белорусский языки, где используется до сих пор [Besters-Dilger, 1997, p. 27-28]; в современном польском деловом языке powinien выражает долженствование с дополнительной модальной семой вынужденности [Магдалинская, 2015, с. 15] (см. также: [Магдалинская, 2011, с. 194; Ваулина, Магдалинская, 2012, с. 13-14]).

Модальный предикатив должен известен уже с древнерусской эпохи (семантическая история слова должен представлена в: [Дронова, 2006, с. 191-204]), «в старорусский период начинается его последовательное движение к центру микрополя необходимости» [Ваулина, 1991, с. 29]. В Петровскую эпоху он сохранял живую связь с существительным долг и преимущественно употреблялся в предложениях с личным подлежащим, причем ин- 
финитивная часть была выражена глаголом действительного залога:

(12) Каждый офицер, который в крепости, лагере, на валу, у ворот или в поле караул имеет, должен в том ответ дать... (AB, с. 35 );

(13) ...но каждый [член коллегии] с надлежащим прилежанием и ревностию службу свою отправлять и попечение иметь должен (ГР, с. 11).

Признаки расширения сочетаемости должен можно отметить в Адмиралтейском регламенте:

(14) Должны быть уничтожены всякие росписки или с них списки и цертификаты, которые не таким образом зделаны, как в регламенте положено (АР, с. 15).

Чаще всего в двусоставном предложении при выражении обязывания используется модальный оператор иметь, который сравнительно с другими операторами обладает широкой сочетаемостью как с грамматическим субъектом, так и с приглагольной (инфинитивной) частью. В качестве подлежащего встречаются и личные одушевленные, и предметные неодушевленные существительные. В сочетании с личными существительными (а также местоимениями, обозначающими лицо) иметь может присоединять инфинитив в действительном залоге, инфинитив в страдательном залоге или инфинитивную часть, выраженную сочетанием быть и страдательным причастием:

(15) Президенты и вице-президенты имеют того смотрить, чтоб служители при коллегиях, канцеляриях и канторах до последняго должность свою знали... (ГР, с. 20);

(16) Служба божия имеет отправляться по вся утра и вечеры и полдень... с пением и молением в лагерях... (AB, с. 13);

(17) Того ради надлежит публичному месту быть, где в указное время все наказанье на теле и лишение живота чинено быть имеет... (ГР, с. 35);

(18) Когда офицер при молитве пьян явится, а чрез оное пьянство другим соблазн учинит, тогда оный имеет впервые и вдругоредь арестом у профоса наказан, а втретие на несколько времяни от службы отставлен и рядовым учинен быть (AB, с. 14).

Наиболее частотно употребление модального глагола иметь в сочетании с конструкцией «быть + страдательное причастие». Возможно и безличное употребление иметь:
(19) В обозе всюды чисто держано имеет быть... (AB, с. 66).

Хотя конструкция «иметь + инфинитив» известна в древнерусском языке как один из способов выражения будущего времени с оттенком долженствования [Дронова, 2006, c. 205-207], изредка желательности или возможности [Ваулина, 1988, с. 44], ее распространение в документах Петровской эпохи в качестве средства выражения обязывания следует отнести к польскому влиянию (mieć + инфинитив), поскольку эта конструкция в модальном значении появляется в русских текстах со второй половины XVI в., то есть тогда же, когда активизируется польское влияние на русский язык. В свою очередь, польская конструкция могла быть результатом либо калькирования немецкой конструкции haben zu (калька XIIXIII вв. французского avoir à), либо влияния средневековой латыни (habeo + инфинитив) [Besters-Dilger, 1997, p. 22-25].

Отметим, что модальное значение конструкции «иметь + инфинитив» в регламентах не всегда возможно отграничить от значения будущего времени, например:

(20) Всякой бунт, возмущение и упрямство без всякой милости имеет быть виселицею наказано (AB, c. 102).

В польском языке mіес́ в сочетании с инфинитивом часто выражает оттенок запланированности действия, семантически соответствуя русскому предстоит, «для официальноделовых документов и научных текстов глагол mіес́ нетипичен» [Магдалинская, 2015, с. 16]. Нельзя исключать, что именно недостаточно ясная модальная семантика глагола иметь способствовала сокращению употребления конструкции «иметь + инфинитив» в более поздних петровских регламентах. Так, в Адмиралтейском регламенте она представлена всего 37 случаями, большинство из них приходится на сочетания с инфинитивом быть:

(21) А у рот первые начальники имеют быть капитаны... (АР, с. 21);

(22) Все палаты в Арсенале имеют построены быть близко воды и крепко зделаны (АР, с. 39).

Кроме полонизмов, в выражении обязывания изредка использовалась церковнославян- 
ская конструкция «да + форма настоящего / будущего времени глагола»:

(23) Овощные воры, такожде которые дрова, кур, гусей и рыбы крадут, по рассмотрению воро<в >ства да накажутся (АВ, с. 140);

(24) ...а взятые за то деньги купно с теми, кои найдутся в корманах [!], да будут употреблены по указу от Коллегии в госпитал (АР, с. 143).

Далее охарактеризуем средства имплицитного выражения обязывания, к которым относится употребление форм настоящего и будущего долженствования, а также конструкции «бывать + страдательное причастие». Хотя формы настоящего и будущего времени глагола еще не закрепились в качестве средства выражения обязывания, обращает на себя внимание их широкое употребление, поскольку в контексте регламента они приобретают оттенок долженствования:

(25) Ежели же кто против сего поступит и пренебрежет, тот наказан будет денежным штрафом... (ГР, с. 7);

(26) Естьли сие офицер учинит, лишится чина своего и имеет за рядового служить... (АВ, с. 39).

Можно отметить следующие особенности употребления в регламентах форм будущего времени в качестве средства выражения обязывания: 1) они используются для выражения страдательного залога, доминирует конструкция «будет / будуm + страдательное причастие»; 2) их использование ограничено главной частью сложноподчиненного предложения с придаточным условным (придаточная часть выражает гипотезу правовой нормы, главная часть - ее диспозицию).

Сходно употребление конструкции «бывать + страдательное причастие прошедшего времени», в которой подчеркивается повторяемость и результативное значение:

(27) Еще такожде повешены бывают оные, которые в дезертировании поимаются (АВ, с. 75);

(28) Члены коллегиев ни к каким другим делам употреблены не бывают, кроме что чину их принадлежит... (ГР, с. 12).

Формы настоящего времени для выражения обязывания часто использованы в Генеральном регламенте и редко в военных регламентах. Возможно, это обусловлено тем, что значение настоящего долженствования в документах петровского времени реализовывалось еще недостаточно четко:

(29) Сколь скоро коллегиум в вышепомянутое время и часы соберется, хотя и не все, но большая часть членов, то доносит и чтет секретарь все в надлежащем порядке... (ГР, с. 7).

Распространение настоящего предписания происходит в эпоху Екатерины II.

В рассматриваемых документах обнаруживается взаимодействие разных форм выражения обязывания:

(30) Одним президентам, когда они присудствуют, надлежит от его императорского величества и от Сената в коллегии присылаемые указы распечатывать, а другие все из провинцей и из других коллегей приходящия ведомости и письма распечатывает, кто первой по президенте, и потом оныя от секретарей чтены бывают по содержанию пятой главы сего регламента... (ГР, с. 15).

Примеры одновременного использования разных способов выражения обязывания, видимо, следует трактовать как признак отсутствия грамматикализации этих средств и системных связей между ними: в деловой речи происходил поиск наиболее точных моделей выражения обязывания путем уточнения их функций и преодоления полиномии.

\section{Выражение разрешения}

Разрешение, как и обязывание, выражается при помощи двусоставных и односоставных (безличных) предложений. Безличные конструкции содержат модальные предикативы можно, свободно, близкое к безличному свобода дается (в сочетании с инфинитивом):

(31) ...pазве когда президенты за болезнью или других помешательств ради в коллегиум не могут быть, то можно им к себе секретаря или нотариуса призвать и чрез оных мнение свое коллегию объявить... (ГР, с. 16);

(32) ...но надобно оное исправить, а по окончании той работы свободно есть ему [солдату] о неправом командировании жалобу принесть... (ГР, с. 43),

либо (квази)безличные глагольные формы позволяется, позволено, допущается, допущее- 
но, не запрещяется (в сочетании с инфинитивом или отглагольным существительным):

(33) ...а ежели неможно сыскать столько потребных российской нации [матросов], то позволяется нанимать и иноземцов, но токмо чтоб не более четвертой доли (АР, с. 26);

(34) Впрочем, в правах позволено вора, который в ночи в дом ворвется, без страху наказания умертвить, ежели его без своего опасения преодолеть было невозможно... (АВ, с. 138);

(35) ...и такое ему [преступнику] пременение имяни в правах допущается и не запрещается $(\mathrm{AB}, \mathrm{c.} 147)$.

В двусоставной конструкции разрешение выражается при помощи глагола мочь:

(36) ...тогда может офицер потерянием ружья своего, из котораго он стрелял, и вычетом жалованья его на несколько месяцов, а рядовой шпицрутенами наказан быть (AB, с. 33);

(37) ...но ежели кто будет ранен или болен, тогда может он о том офицеру возвестить и обождать, пока ему надлежащее позволение отлучитися дано будет (АВ, с. 69).

Двусоставная конструкция со значением разрешения может содержать глагол позволять (изволять, соизволять) и грамматический субъект, указывающий на источник волеизъявления (чаще всего - его императорское величество, реже - регламент):

(38) И позволяет его императорское величество коллегиям самим угодные способы о том... в доношение учинить (ГР, с. 30).

Выражение разрешения редко встречается в регламентирующих документах петровского времени.

\section{Выражение запрета}

Запрет выражается независимым инфинитивом с отрицанием (это наиболее частотная форма):

(39) ...и когда апробуется, тогда не производить в дело безписменнаго указу (ГР, с. 6);

(40) Мастеровых людей не переводить от одного мастерства к другому (АР, с. 86),

а также формами настоящего времени глаголов запрещзается, не позволяется, причас- тием не позволено в сочетании с инфинитивом, отглагольным существительным или в сочетании с придаточной частью в составе сложного предложения, которая присоединяется с союзом чтоб / дабы:

(41) Того ради чрез сие все идолопоклонство, чародейство (чернокнижество) наикрепчайшее запрещается... (AB, с. 8);

(42) ...и того ради не позволяетца, чтоб которой фамилии одной все были во одной гражданской службе, но, по препорции, и воинской (ГР, с. 28);

(43) ...понеже никому не позволено в коллегии о других делах разговоры иметь... (ГР, с. 18).

Выражение запрета при помощи модального слова с отрицанием не может в сочетании с инфинитивом лишено однозначности, которая характерна для перечисленных выше форм и конструкций:

(44) Однако ж они [арматоры $\left.{ }^{3}\right]$ не могут взять ни единаго матроза из Адмиралтейства, разве о том в коллегию будет дан указ от его величества (AP, c. 33);

(45) По сему артикулу никакой офицер, ни салдат не может оправдатися, хотя с ним от фельдмаршала и генерала непристойным образом поступлено будет и ему от них некоторым образом оскорбление славы учинится... (АВ, с. 23).

В примере (45) не может интерпретируется и как отсутствие возможности, и как запрет; это характерно и для других случаев употребления не может, хотя весьма редких.

В эксплицитной форме запрет выражается при помощи речевой формулы его императорское величество не позволяет, где представлен субъект волеизъявления:

(46) Такоже не позволяет его императорское величество, чтоб в прихожих каморах коллегии какие писари или подьячие сидели и дел тамо отправляли... (ГР, с. 30$)$.

В военных регламентах частотным средством выражения запрета являлась аналитическая форма повелительного наклонения глагола дерзать 'сметь, осмеливаться, решаться на что-л.' (СлРЯ XVIII, вып. 6, с. 108) с отрицанием и в сочетании с инфинитивом. Чаще всего запрет выражался при помощи частицы $\partial а$ и формы настоящего времени либо формой сослагательного наклонения глагола не дерзать 
(в Артикуле воинском 41 и 7 случаев употребления соответственно):

(47) Всем офицерам и рядовым надлежит священников любить и почитать, и никто да не дерзает оным как словом, так и делом досаду чинить, и презирать, и ругаться $(\mathrm{AB}$, с. 15$)$;

(48) А когда его [солдата] очередь к караулу или работе его величества придет, онаго бы отнюдь за своею работою удерживать и препятствовать не дерзали (АВ, с. 45).

\section{Интенсификаторы обязывания и запрета}

Использование интенсификаторов модальных значений обязывания и запрета связано с их сходством в выражении «строго определенного предписания действовать или воздержаться от действия в некоторых условиях, описываемых гипотезой» [Эйсман, 1972, с. 82].

В текстах петровских регламентов и уставов в функции интенсификаторов употреблены прежде всего наречия и наречные сочетания с интенсифицирующим значением: без всякаго мотчания, весьма 'совсем, вполне' (СлРЯ XVIII, вып. 3, с. 76), всеконечно, всемерно, зело, как скоро (скорее) возможно, надлежащим образом, наикрепчайще, (на)крепко, немедленно, необходимо, неотложно, неотменно, непременно, никакой нужды ради, ни под каким видом, отнюд(ь) 'совсем, вовсе, никоим образом' (СлРЯ XVIII, вып. 18, с. 37), прилежно, сколь скоро возможно, сколько возможно, с надлежашим прилежанием и ревностию и др.:

(49) Також имеет подчиненный от всякаго непристойнаго рассуждения об указах, которые ему от начальника даны, весьма воздержаться (AB, c. 26);

(50) Все указы, которые или в лагерях, или в крепостях при трубах, барабанах или при пароле объявятся, имеет каждый необходимо исполнять (AB, c. 30-31);

(51) ...чего президенту и членам Адмиралтейской коллегии надлежит смотреть накрепко (АР, с. 26);

(52) ...и такого наверстывания отнюд не допускать и не подписывать, но також протестовать (AP, c. 42).

Из перечисленных интенсификаторов регулярную представленность в регламентах демонстрируют наречия весьма, отнюдь, немедленно, (на)крепко. Лексическая пестрота была обусловлена новизной употребления этого класса слов, со временем их количество уменьшалось, а состав стабилизировался. Разные интенсификаторы характеризовали разные аспекты совершения предписываемого действия - быстроту (немедленно, неотложно, без мотчания), активность адресата при его выполнении (прилежно, накрепко, с надлежащим прилежанием, с надлежащим старанием), соответствие установленному порядку (неотменно, непременно, надлежащим образом), полноту достижения результата или запрета (весьма, отнюдь). При выражении запрета интенсификаторами регулярно выступали также отрицательные местоимения и местоименные наречия, усиливавшие полноту запрета, - никто, нигде и проч.:

(53) ....а без отпуску никому никуды отъежжать не позволяется... (АР, с. 11).

Способом усиления предписания в реглементах петровского времени является указание на разного рода кары за его неисполнение: под опасением лишения чести и живота, под потерянием живота, под лишением живота, под опасением жестокаго наказания, под наказанием смерти, без всякой милости, под смертною казнию, под наказанием смертным, под опасением штрафа, под лишением жалованья и мн. др.

Регламентирующие документы Петровской эпохи характеризуются высокой плотностью употребления интенсификаторов при выражении обязывания и запрета. Отчасти это было обусловлено влиянием европейских образцов, отчасти - новизной регламентирующих жанров и, возможно, опасением адресанта документа, что из-за недостаточной дисциплины со стороны адресата регламентов они не будут выполняться. Все это создает специфическую жесткую тональность петровских регламентов. Следует, однако, иметь в виду, что власть пыталась повысить эффективность выполнения регламентирующих документов не только устрашением, но и разъяснениями. Так, в Артикуле воинском встреча- 
ются многочисленные толкования к артикулам, выделенные графически, в других регламентах и уставах толкование включается в текст, например:

(54) Понеже должность его [нотариуса] чина В том состоит, чтоб он при собрании коллегии протокол держал, того ради надлежит ему оной следующим образом сочинять (ГР, 23).

При выражении разрешения интенсификаторы обычно не употребляются, однако в качестве исключения можно отметить и такие случаи:

(55) Такожде не вельми охотно позволяется, чтоб офицер другаго, которой караулу в том месте не имеет, на караул с собою брал... (АВ, с. 35).

В данном примере сочетание не вельми охотно ослабляет предоставляемую возможность выбора, с одной стороны, и актуализирует субъекта волеизъявления, который предоставляет разрешение, с другой стороны.

\section{Выводы}

Петровские регламенты представляли собой новый жанр в российской деловой коммуникации, речевое оформление которого потребовало привлечения новых языковых средств. Значительной трансформации и обновлению подверглись средства выражения императивности, использовавшиеся в деловых текстах. Наряду с традиционно употреблявшимся для выражения обязывания инфинитивом, тексты регламентов содержат большое количество новых средств (надлежит, должен и проч. в сочетании с инфинитивом, формы настоящего и будущего времени глагола), в том числе заимствованных - полонизмов, германизмов, латинизмов (иметь, повинен в сочетании с инфинитивом и др.). Новизна используемых средств проявлялась и в случаях их контаминации типа да долженствует (+ инфинитив), да не имеет (+ инфинитив).

Изменения в репертуаре императивных средств были обусловлены различными причинами: семантическими (необходимость точнее выразить императивное значение), стилистическими (стремление «окнижить» деловой текст), социокультурными (утверждение двусоставной модели, где субъект-исполни- тель занимал позицию подлежащего для выражения императивности под влиянием европейских текстовых образцов).

Императивную тональность петровских регламентов можно охарактеризовать как жесткую. Для ее усиления использовался широкий круг различных интенсификаторов, которые подчеркивали полноту запрета, необходимость совершать предписанное действие быстро, согласно установленной модели поведения, с внутренним напряжением и т. д. Усилению обязывания и запрета в регламентах способствовали угрозы наказания за несовершение предписанного действия. Необходимость употребления интенсификаторов была обусловлена, видимо, новизной регламентирующих текстов и опасением государя, что такие тексты не будут в полной мере эффективны как средство управления. Вместе с тем в регламентах можно обнаружить стремление адресанта убедить адресата в необходимости совершения предписываемых действий посредством разъяснения - что типично для деловой коммуникации петровского времени.

\section{ПРИМЕЧАНИЯ}

${ }^{1}$ Исследование выполнено при финансовой поддержке РФФИ, проект № 20-012-00338 «Система средств выражения императивности в русском деловом языке XVIII века».

The reported study was funded by Russian Foundation for Basic Research (RFBR), the projects no. 20-012-00338 "The system of imperative means in the Russian official language of the XVIII century”.

${ }^{2}$ При подсчете инфинитивные предложения, занимавшие однородную позицию в составе сложного предложения, учитывались как одна форма. Это связано с тем, что некоторые другие формы выражения обязывания, например «иметь + инфинитив», «надлежит + инфинитив», регулярно употребляются с однородными зависимыми инфинитивами.

${ }^{3}$ Арматор - 'лицо, снаряжающее вооруженное судно для захвата купеческих кораблей неприятеля' (СлРЯ XVIII, вып. 1, с. 92).

\section{СПИСОК ЛИТЕРАТУРЫ}

Бондарко А. В., 1990. К анализу категориальных ситуаций в сфере модальности: императивные ситуации // Теория функциональной грамма- 
тики. Темпоральность. Модальность. Л. : Наука. Ленингр. отд. С. 80-89.

Бошно С. В., 2014. Способы и методы правового регулирования // Право и современные государства. № 3. С. 52-60.

Ваулина С. С., 1988. Эволюция средств выражения модальности в русском языке (XI-XVII вв.). Л. : Изд-во ЛГУ. 143 с.

Ваулина С. С., 1991. Эволюция средств выражения модальности в русском языке (XI-XVII вв.) : автореф. дис. ... д-ра филол. наук. Л. 38 с.

Ваулина С. С., Магдалинская Е. Н., 2012. Модальное микрополе необходимости в официально-деловых документах русского и польского языков // Вестник Балтийского федерального университета им. И. Канта. № 8. С. 12-17.

Дронова Л. П., 2006. Становление и эволюция модально-оценочной лексики русского языка: этнолингвистический аспект. Томск : Изд-во Том. ун-та. $256 \mathrm{c}$

Качалкин А. Н., 1989. Жанры русского документа допетровской эпохи в историко-лингвистическом и источниковедческом освещении : автореф. дис. ... д-ра филол. наук. М. 48 с.

Колобкова Л. В., 1995. Средства выражения модального значения волеизъявления в русском языке XVII - начала XVIII веков : автореф. дис. ... канд. филол. наук. Тверь. 24 с.

Комлева Е. В., 2003. Лингвостилистические особенности выражения побудительности в текстах официально-деловой прозы (на материале современного немецкого языка) : автореф. дис. ... канд. филол. наук. СПб. 18 с.

Магдалинская Е. Н., 2011. Экспликаторы модального значения необходимости в русском и польском языках (на материале научных текстов) // Вестник Волгоградского государственного университета. Серия 2, Языкознание. 2011. №2 (14). С. 192-196.

Магдалинская Е. Н., 2015. Ситуативная модальность как функционально-семантическая полевая структура (на материале современных русского и польского языков) : автореф. дис. ... канд. филол. наук. Калининград. 23 с.

Орлова Н. В., 2014. Модальность и тональность современных документов с предписывающей функцией // Вестник Омского университета. № 4. С. $188-193$.

Соколова М. А., 1952. Выражение волеизъявления в русских бытовых и деловых памятниках XVI века // Ученые записки ЛГУ. № 161. C. 52-79.

Шарипова Р. Р., 2014. Композиционно-речевая организация текста регламента как регулирующего документа // Вестник Волгоградского государственного университета. Серия 2, Язы- кознание. № 2 (21). С. 82-89. DOI: http:// dx.doi.org/10.15688/jvolsu2.2014.2.11.

Ширинкина М. А., 2018. Регламентирующие документы исполнительной власти в аспекте тональности (сопоставительно с директивными) // Политическая лингвистика. № 1 (67). С. 120-130.

Эйсман А. А., 1972. Вопросы структуры и языка уголовно-процессуального права // Вопросы борьбы с преступностью. Вып. 15. С. 71-99.

Besters-Dilger J., 1997. Модальность в польском и русском языках : Историческое развитие выражения необходимости и возможности как результат вне- и межславянского влияния //Wiener Slavistisches Jarhbuch. Vol. 43. S. 17-31.

\section{ИСТОЧНИКИ И СЛОВАРИ}

$A B$ - Артикул воинский купно с процессами. Напечатан вторым тиснением. СПб. : [Тип. Акад. наук], 1756. $231 \mathrm{c.}$

АИ - Акты исторические, собранные и изданные Археографическою комиссиею. Т. 2. 15981613. СПб. : В Тип. Экспедиции заготовления гос. бумаг, 1841. IV, 438, 29 с.

$A P$ - Регламент благочестивейшаго государя Петра Великаго, отца отечества, императора и самодержца всероссийскаго, о управлении Адмиралтейства и верфи и о должностях Коллегии адмиралтейской и прочих всех чинов при Адмиралтействе обретающихся... СПб. : Тип. Мор. шляхет. кадет. корпуса, 1764. 202, 13 c.

$Г P$ - Его императорскаго величества Генеральный регламент или Устав, по которому государственные коллегии, також и все оных приналежащих к ним канцелярей, и кантор служители, не токмо во внешних и внутренних учреждениях, но и во отправлении своего чина, подданнейше поступать имеют. СПб. : При Имп. Акад. наук, 1735. 41 с.

СлРЯ ХVIII - Словарь русского языка XVIII века / АН СССР. Ин-т рус. яз. ; гл. ред. Ю. С. Сорокин. Вып. 1-6. Л. : Наука. Ленингр. отд-ние, 1984-1991 ; Вып. 7-22. СПб. : Наука. С.-Петерб. отд-ние, 1992-2019.

\section{REFERENCES}

Bondarko A.V., 1990. K analizu kategorialnykh situatsiy v sfere modal'nosti: imperativnye situatsii [On the Analysis of Categorical Situations in the Field of Modality: Imperative Situations]. Teoriya funktsionalnoy grammatiki. Temporalnost. Modalnost' [Functional Grammar Theory. 
Temporality. Modality]. Leningrad, Nauka, Leningradskoe otdelenie Publ., pp. 80-89.

Boshno S.V., 2014. Sposoby i metody pravovogo regulirovaniya [Means and Methods of Legal Regulation]. Pravo i sovremennye gosudarstva [Law and Modern States], no. 3, pp. 52-60.

Vaulina S.S., 1988. Evolyutsiya sredstv vyrazheniya modal'nosti $v$ russkom yazyke (XI-XVII vv.) [Evolution of the Means of Expressing Modality in Russian $\left(11^{\text {th }}-17^{\text {th }}\right.$ Centuries $\left.)\right]$. Leningrad, Izd-vo LGU. 143 p.

Vaulina S.S., 1991. Evolyutsiya sredstv vyrazheniya modal'nosti $v$ russkom yazyke (XI-XVII vv.): avtoref. dis. ... d-ra filol. nauk [Evolution of the Means of Expressing Modality in Russian ( $11^{\text {th }}$ $17^{\text {th }}$ Centuries). Dr. philol. sci. abs. diss.]. Leningrad. $38 \mathrm{p}$.

Vaulina S.S., Magdalinskaya E.N., 2012. Modalnoe mikropole neobkhodimosti v ofitsialno-delovykh dokumentakh russkogo i pol'skogo yazykov [The Modal Microfield of Necessity in Official and Business Documents in the Russian and Polish Languages]. Vestnik Baltiyskogo federal'nogo universiteta im. I. Kanta [Vestnik IKBFU], no. 8, pp. 12-17.

Dronova L.P., 2006. Stanovlenie i evolyutsiya modalnootsenochnoy leksiki russkogo yazyka: etnolingvisticheskiy aspekt [Formation and Evolution of Modal-Evaluative Vocabulary of the Russian Language: Ethnolinguistic Aspect]. Tomsk, Izd-vo Tomskogo universiteta. $256 \mathrm{p}$.

Kachalkin A.N., 1989. Zhanry russkogo dokumenta dopetrovskoy epokhi $v$ istoriko-lingvisticheskom i istochnikovedcheskom osveshchenii: avtoref. dis. ... d-ra filol. nauk [Genres of Russian Document of the Pre-Petrine Era in HistoricalLinguistic and Source Study Aspects. Dr. philol. sci. abs. diss.]. Moscow. 48 p.

Kolobkova L.V., 1995. Sredstva vyrazheniya modal'nogo znacheniya voleizyavleniya $v$ russkom yazyke XVII - nachala XVIII vekov: avtoref. dis. ... kand. filol. nauk [Means of Expressing the Modal Meaning of the Expression of Will in the Russian Language of the $17^{\text {th }}$ Early $18^{\text {th }}$ Centuries. Cand. philol. abs. sci. diss.]. Tver. $24 \mathrm{p}$.

Komleva E.V., 2003. Lingvostilisticheskie osobennosti vyrazheniya pobuditelnosti $v$ tekstakh ofitsialno-delovoy prozy (na materiale sovremennogo nemetskogo yazyka): avtoref. dis. ... kand. filol. nauk [Linguo-Stylistic Features of Expressing Incentive in the Official Texts (Based on the Material of Modern German). Cand. philol. abs. sci. diss.]. Saint Petersburg. 18 p.

Magdalinskaya E.N., 2011. Eksplikatory modal'nogo znacheniya neobkhodimosti $\mathrm{v}$ russkom $\mathrm{i}$ pol'skom yazykakh (na materiale nauchnykh tekstov) [Explications of Modal Meaning of Necessity in Russian and Polish Languages (On the Basis of Scientific Texts)]. Vestnik Volgogradskogo gosudarstvennogo universiteta. Seriya 2. Yazykoznanie, no. 2 (14), pp. 192-196.

Magdalinskaya E.N., 2015. Situativnaya modalnost kak funktsionalno-semanticheskaya polevaya struktura (na materiale sovremennykh russkogo i pol'skogo yazykov): avtoref. dis. ... kand. filol. nauk [Situational Modality As a FunctionalSemantic Field Structure (Based on the Material of Modern Russian and Polish Languages). Cand. philol. abs. sci. diss.]. Kaliningrad. 23 p.

Orlova N.V., 2014. Modalnost i tonalnost sovremennykh dokumentov s predpisyvayushchey funktsiey [Modality and Tonality of Contemporary Documents with Prescriptive Function]. Vestnik Omskogo universiteta [Herald of Omsk University], no. 4, pp. 188-193.

Sokolova M.A., 1952. Vyrazhenie voleizyavleniya v russkikh bytovykh i delovykh pamyatnikakh XVI veka [Expression of Will in Russian Everyday and Document Texts of the $16^{\text {th }}$ Century]. Uchenye zapiski $L G U$, no. 161, pp. 52-79.

Sharipova R.R., 2014. Kompozitsionno-rechevaya organizatsiya teksta reglamenta kak reguliruyushchego dokumenta [The Compositional and Speech Organization of Regulation Text As a Regulatory Document]. Vestnik Volgogradskogo gosudarstvennogo universiteta. Seriya 2. Yazykoznanie [Science Journal of Volgograd State University. Linguistics], no. 2(21), pp. 82-89. DOI: http://dx.doi.org/10.15688/ jvolsu2.2014.2.11.

Shirinkina M.A., 2018. Reglamentiruyushchie dokumenty ispolnitelnoy vlasti $\mathrm{v}$ aspekte tonalnosti (sopostavitelno s direktivnymi) [Regulatory Documents of the Executive Power in the Aspect of Tonality (Compared to Directory Ones)]. Politicheskaya lingvistika [Political Linguistics], no. 1 (67), pp. 120-130.

Eysman A.A., 1972. Voprosy struktury i yazyka ugolovno-protsessualnogo prava [Questions of the Structure and Language of Criminal Procedure Law]. Voprosy borby s prestupnostyu [Anti-Crime Issues], iss. 15, pp. 71-99.

Besters-Dilger J., 1997. Modalnost v polskom i russkom yazykakh: Istoricheskoe razvitie vyrazheniya neobkhodimosti i vozmozhnosti kak rezul'tat vne- i mezhslavyanskogo vliyaniya [Modality in Polish and Russian. Historical Development of the Expression of Necessity and Possibility As a Result of Extra- and InterSlavic Influence]. Wiener Slavistisches Jarhbuch, vol. 43, S.17-31. 


\section{SOURCES AND DICTIONARIES}

Artikul voinskiy kupno s protsessami. Napechatan vtorym tisneniem [Military Articles with Processes. The Second Edition]. Saint Petersburg, Tipografiya Akademii Nauk, $1756.231 \mathrm{p}$.

Akty istoricheskie, sobrannye $i$ izdannye Arkheograficheskoyu komissieyu. T. 2. 15981613 [Historical Acts Collected and Published by the Archaeographic Commission. Vol. 2. 15981613]. Saint Petersburg, Tipografiya Ekspeditsii zagotovleniya gosudarstvennykh bumag, 1841 . IV, 438, $29 \mathrm{p}$.

Reglament blagochestiveyshago gosudarya Petra Velikago, ottsa otechestva, imperatora $i$ samoderzhtsa vserossiyskago, o upravlenii Admiralteystva $i$ verfi i o dolzhnostyakh Kollegii admiralteyskoy i prochikh vsekh chinov pri Admiralteystve obretayu-shchikhsya... [Regulations of the Most Pious Sovereign Peter the Great, Father of the Fatherland, Emperor and Autocrat of AllRussian, on the Management of the Admiralty and Shipyard and on thePosts of the Admiralty Collegium and Other All Ranks in the Admiral...]. Saint Petersburg, Tipografiya Morskogo shlyakhetnogo kadetskogokorpusa, 1764.202,13 p.

Ego imperatorskago velichestva Generalnyy reglament ili Ustav, po kotoromu gosudarstvennye kollegii, takozh $i$ vse onykh prinalezhashchikh $k$ nim kantselyarey, $i$ kantor sluzhiteli, ne tokmo vo vneshnikh $i$ vnutrennikh uchrezhdeniyakh, no $i$ vo otpravlenii svoego china, poddanneyshe postupat imeyut [His Imperial Majesty General Regulations or Statutes, According to Which the State Colleges, As Well As All the Servants of Their Chanceries and Offices, not Only in External and Internal Institutions, but Also in the Fulfillment of Their Rank Duty have to Humbly Act]. Saint Petersburg, Imperatorskaya akademiya nauk, $1735.41 \mathrm{p}$.

Sorokin Yu.S., ed. Slovar russkogo yazyka XVIII veka [Dictionary of the Russian Language of the $18^{\text {th }}$ Century], iss. 1-6. Leningrad, Nauka, Leningradskoe otdelenie Publ., 1984-1991; iss. 7-22. Saint Petersburg, Nauka, SanktPeterburgskoe otdelenie Publ., 1992-2019.

\section{Information About the Authors}

Dmitriy V. Rudnev, Doctor of Sciences (Philology), Professor, Department of Russian Language, Acting Dean, Faculty of Philology, Herzen State Pedagogical University of Russia, Reki Moyki Emb., 48, 191186 Saint Petersburg, Russia, rudnevd@mail.ru, https://orcid.org/0000-0002-3264-9483

Natalia V. Pushkareva, Doctor of Sciences (Philology), Associate Professor, Department of Russian Language, St. Petersburg State University, Universiteskaya Emb., 11, 199034 Saint Petersburg, Russia, pushkarevanata@gmail.com, https://orcid.org/0000-0001-7918-5420

\section{Информация об авторах}

Дмитрий Владимирович Руднев, доктор филологических наук, профессор кафедры русского языка, и. о. декана филологического факультета, Российский государственный педагогический университет им. А.И. Герцена, наб. реки Мойки, 48, 191186 г. Санкт-Петербург, Россия, rudnevd@mail.ru, https://orcid.org/0000-0002-3264-9483

Наталия Викторовна Пушкарева, доктор филологических наук, доцент кафедры русского языка, Санкт-Петербургский государственный университет, Университетская наб., 11, 199034 г. Санкт-Петербург, Россия, pushkarevanata@gmail.com, https://orcid.org/0000-0001-7918-5420 